\title{
Social Wasps and Their Ways
}

\section{Some Interesting Facts About These Familiar Insects \\ By Harold Bastin}

ThE true wasps, which may be distinguished from all other Hymenoptera by the longitudinal folding of the fore-wings when the insect is at rest, fall naturally into two groups. In the first group (Eumenides) the shin or tibia of the midule leg has only one spine at the tip, and the claws of all the feet are toothed; in the second group (Vespida) there are two tibial spines on the middle leg, and the claws of the feet are simple. It is to the latter group, commonly called "social wasps," that the following paragraphs will apply, while specia reference will be made to the typical genus Vespa, the yellow and black species, which are notable for their large co-operative communities, and for the elaborate corerel nests which they construct. Nearly all the other social wasps in the United States are long-bodied, black insects referable to the genus Polistes. Thei communities are far less populous than is the case with Vespa, while their nests consist of a single comb without any envelop.

Social wasps employ a material for the construction of their habitations which is quite unique in the economy of insect life. It consists of woodfiber, rasped by the wasps from tree trunks and fences, and worked un with their adhesive saliva to form a substance which is essentially paper. IVasps, in fact, are the original paper-makers; and Dr. L. O. Howard remarks that "It is quite within the possibilities that the papermaking idea in the human species was gained from the obserration of these insects. Their paper, however, is made from wood-pulp-a late development in the scale of human ingenuity."

The communal life of social wasps, during the summer, is not unlike that of the hive-bee. In each nest we find one fertile female-the foundress of the colony, and a daily increasing number of sterile females or "workers." But whereas communities of hive-bees tlianks, mainly, to the habit of "swarming," and to the great store of provisions which is accumulated in the nest for winter use--are able to continue indefinitely, those of social wasps endure only from spring to fall.

Social wasps build their nests among the branches of shrubs and trees, in the cavities of decaying trunks, among the rafters of barns or outhouses, or in holes beneath the surface of the ground-the nesting habits being, as a rule, characteristic in the case of each species. Early in the year, one may often see large waspls searching for suitable nesting sites. These are all pregnant queens which have hibernated in sheltered nooks and crannies during the cold weather. Each is the prospective foundress of a new colony. Many of these lone queens are destroyed by birds and other insectivorous creatures. Many fall victims to inclemencies of the weather. But those that escape construct the small, stalked combs of brood cells which, by continual additions, will grow into the great nests of summer. Within each cell the queen wasp lays an egg. When the eggs hatch, she goes abroad on foraging expeditions, and brings home burdens of food for her little family-sweet juices, it may be, or the soft tissues of newly sliughtered insects. Thus nourished, her offspring thrive, pass quickly through their transformations, and emerge as fully developed worker wasps, capable of assisting their queen-mother in her labors of building and foraging. Indeed ere many weeks have elapsed, the queen's power of paper-making fails, owing to the exhaustion of her salivary glands, and she the population of the nest grows rapidly, and the success of the community is assured.

The venomous stings of social wasps, and the extreme irritability by which these insects are characterized, render the study of their economy no easy matter. Nevertheless, the exercise of tact and courage, and still more perhaps the ingenious methods which have been devised for keeping wasp colonies in glazed hives under constant observation, have laid bare the lifehistories of many species. We know that the queen fixes her elongate, white egg to the side of the cell, and that when the tiny grub hatches it remains at first with its posterior extremity attache to the egg-shell, moving upon this pivot, and craning its head towards the mouth of the cell to receive food from the workers. It is a peculiarity of social wasp architecture that the combs are suspended so that the openings of the cells point downwards. Thus, when the young grub changes its position-as it must soon do in order to profit by the full accommodation which the cell affords-it occasionally falls headlong from the cell, for it has only two grasping organs, namely, its jaws and a kind of sucker foot at its tail-end. These fallen grubs are rarely re placed by the workers, but are carried out of the nest and left to die. But the lucky grub which succeeds in planting its sucker foot firmly against the roof of its cell soon grows so fat that it completely fills its cradle It is regularly fed and groomed by its nurses, and when full-grown it spins a silken cap over the mouth of its cell and passes into the pupa state. The perfect wasp eventually breaks through the silken cap, and mingles with the adult population of the community. She remains in the nest for some days, however, before she ventures forth into the open to gather building materials. Thereafter she devotes her energies chiefly to paper-making until, some three weeks later, her salivary glands are exhausted, when she joins the ranks of the foragers and nurses.

At the close of summer, a prosperous Vespa colony may number anything from several hundreds to many thousands of individuals. "In one large nest (write Dr. Howard) I counted 1,135 cells, and since the worker cells are used two or three times in the summer, the colonies become very strong. This count was made with the large bald-face hornet (Vespa maculata) but in some of the smaller wasps or yellow-jackets, like Vespa germanica, the cells are even more numerous. In one nest of the latter species, Mr. Marlatt tells me one nest of the latter species, Mr. Marlatt tells me
that he carefully estimated that it contained about fourteen thousand cells."

The nests built by all the species of Vespa are es sentially alike in architecture. The small comb originally constructed by the foundress queen is widened $y$ the workers, and other combs are attache to it by portions, the nest may consist of seven combs, all proportions, the nest may consist of seven combs, all pro-
tected by a stout outer cover, the whole structure hanging from a branch, root or other suitable support-for social wasps invariably suspend their nests, never building upwards from a solid foundation. The outer cover of the nest always appears smooth and complete for as the wasps enlarge the combs by adding cells to their edges, they cut away the inner layers of the envelop, and continually add more material from without. Access to the interior of the nest is gaine through a small hole at its lower extremity. In the case of subterranean nests, the worker wasps are constantly occupied in enlarging the cavity in which the nest is suspended from the root of some plant. Small particles of earth and stone are carried out bodily, but pebbles and fragments which are too heavy for the insects to cope with are systematically undermined and allowed to gravitate to the floor of the cavern Large projecting corners of rock which can neithe be removed nor displaced are perforce ignored, an these obstacles occasionally affect the symmetry of th nest, the normal shape of which is roughly spherical.

As summer wanes, certain large cells are prepared by the workers, and in these the queen-mother deposits individuals-arones or males, and young princoses females. The amours and merrymaking of these royal personages keep the community in a whirl of joyous activity, for the advent of potential queens is no among wasps the signal for revolution, as is the case with bees. The prosperity of the nest seems to be unabated; but the prescient observer is aware that the downfall of the great community will soon be accomplished. As the chill grasp of approaching winter settles upon the land, the workers become enfeebled, and cease to tend their grubs or to roam abroad in search of food. Thus they die-die by tens, by hundreds, by thousands. The drones share the common fate after mating the young princesses. Only the latter survive destined as they are to found fresh colonies in the succeeding year. As each seeks out her lonely winter hiding-place, she seems more like a wretched

The best known social wasp in the United States is the bald-faced hornet to which reference has alread been made. Its nests are commonly seen attached to the branches of trees. The larger Vespa crabro is really a native of Europe. It was accidentally imported many years ago and established itself in the vicinity of New York city. It has since spread and multiplied to some extent, but is by no means common or widely distributed. It builds preferably in the hollow trunks of old trees, but sometimes resorts to
the rafters of a barn or outhouse. The smaller yellowjacket wasps (e. g. Vespa germanica and V. cuneata) build in various situations, sometimes in subterranean cavities, sometimes above ground, in the hollows of stumps or beneath stones. The nests of the Polistes wasps are familiar objects in country barns, or attached to the twigs of bushes. They consist of a single comb, without a cover. The number of individuals in the colony is always small, and these wasps must be regarded as much less highly civilised than those of the genus Vespa.

For the finest specimens of wasp architecture we must go to the tropics. Brazilian wasps of the genera Polybia, Chartergus, etc., build enormous nests, the outer covering of which is so thick and hard that it resembles pasteboard. The outer surface is so smooth that one may write upon it with ink and a fine pen. Such nests as these are very durable, and there is reason for thinking that in some instances the colonies which inhabit them may persist for more than one season. It is said, too, that some of these tropical social wasps store nectar in their abodes after the manner of bees.

From the agriculturist's point of view, the most important item of knowledge concerning wasps is how best to destroy them. Social wasps do some good to man by capturing and killing noxious insects, but the benefit which they thus confer is more than counterbalanced by the enormous damage which they accomplish in plantations and orchards. The large underground colonies may be exterminate by pouring in a little bisulphide of carbon, and stopping the entrance hole with a sod; the nests which are suspended in trees and bushes may be easily destroyed by drenching them with kerosene. These operations should always be performed after wise there is great danger of being stung.

\section{Scattering of Light by Air Molecules}

IN a recent paper [Sci. Abs. 835 (1918)] Strut described experiments on the scattering of light by dust-free air. Wood, in 1902, carried out experiments practically identical as regards method and results Strutt, but the results were found to be spurious. A spark was used as the source of light It was found that if the spark was stopped and the tube thoroughly washed out with purified air, abso-
lutely no trace of the cone of scattered light was visible on turning on the spark. In about ten seconds however, a trace of the cone appeared, and after the spark has been in operation for a minute it was wel developed. Interposition of a glass plate prevented the formation of the cone. This appeared to prove conclusively that the ultra-violet light caused a precipitation of something from the air, giving rise to a slight cloul. Using sulphuric acid instead of phosphorus pentoxide as a drying agent only made matters worse. Hence it is suggested that Strutt's experiments should be repeated before the scattering of light by air molecules can be considered to have been demonstrated. If, using sunlight and a glass lens, the cone of light cannot be seen with the eye, it would show that Strutt's results were due to a cloud resulting from the action of the ultra-violet rays on the air.-Note in Sci. Absts. on a paper by R. W. Wood in Phil. Mag.

\section{The Nitrogen Content of Oxidized Coals}

THE percentage of nitrogen in coal varies from 0.7 to $2.5 \%$. The author confirms the view of H. Fayol that the main effect of the action of air on coal is to oxidise and dehydrogenate the organic matter, with formation of humic matters. Analyses were made of eight samples of Decazeville coals which heat up readily under the action of oxygen and ignite spontaneously. The specimens were taken at the outcrop at Combes in the vicinity of an interstratification of sandstone, where coals with various degrees of oxidation are formed, from those of 8,000 cals. and $36 \%$ of volatile matter to 5,200 cals. and $52 \%$ of volatile matter. Calculated on the pure coal substance the carbon ranged from $81.4 \%$ to $64.9 \%$, the hydrogen from $5.3 \%$ to $3.0 \%$, the nitrogen from $1.7 \%$ to $2.5 \%$, the oxygen and sulphur (by difference) from $11.6 \%$ to $29.6 \%$. The percentage of humic matter in the raw coal increased from $0.5 \%$ to $70 \%$. Allowing for ash and water, the proportion of nitroge is very little altered except in the coals greatly decomposed and almost completely transformed to humic matter, in which case the nitrogen content appears to ncrease, approaching the figure met with in ordinary vegetable humic matter.-Note in Jour. Soc. Chem. Ind. on a paper by P. Mahler in Comptes. rend. 